\begin{tabular}{|c|l|}
\hline Title & The Equal Employment Opportunity Law and labor force behavior of women in Japan \\
\hline Author(s) & A be, Yukiko \\
\hline Citation & $\begin{array}{l}\text { Journal of the Japanese and international economies, 25(1), 39-55 } \\
\text { https:/doi.org/L0.1016/.jjie.2010.06.003 }\end{array}$ \\
\hline Issue Date & 2011-03 \\
\hline Doc URL & http://hdl.handle.net/2115/57677 \\
\hline Type & article (author version) \\
\hline File Information & yukiko_abe_EEOL.pdf \\
\hline
\end{tabular}

Instructions for use 


\title{
The Equal Employment Opportunity Law and labor force behavior of women in Japan *
}

\author{
Yukiko Abe $^{* *}$ \\ Graduate School of Economics and Business Administration, \\ Hokkaido University \\ June 2010
}

\begin{abstract}
This study uses repeated cross-sectional data to investigate the impact of the Equal Employment Opportunity Law (EEOL) for men and women enacted in 1986 on labor force behavior of women. I find that regular employment among women, examined separately by education and marital status, did not increase after the enactment of the EEOL. Cohorts of women who graduated from university after the EEOL married later or were less likely to marry than previous cohorts.
\end{abstract}

Keywords: cohort, Equal Employment Opportunity Law, regular employment, part-time employment, Japan.

JEL Classification: J12, J21

\footnotetext{
* This article uses resampled microdata of the Employment Status Survey (ESS) made available through the Research Centre for Information and Statistics of Social Science, Institute of Economic Research, Hitotsubashi University. Resampled microdata cannot be released due to the terms of usage of the data. I thank anonymous referees, Kosei Fukuda, Yoshio Higuchi, Dean Hyslop, Takao Kato (a co-editor), Daiji Kawaguchi, David Máre, Naoki Mitani, Akiko S. Oishi, Hiroshi Ono, Shingo Takagi, Akira Wakisaka, and seminar participants at Hitotsubashi University, Hokkaido University, Kansai Labor Economics Research Group, University of Tokyo, Victoria University at Wellington, and the 2008 Spring Meeting of the Japanese Economic Association for helpful comments. Remaining errors are my own. This research is supported by the Japanese Ministry of Education, Science, Sports and Culture Grant to Hosei University for the International Research Project on Aging (Japan, China, Korea: FY2003 to FY2007) and the Japan Society for Promotion of Science Grant-in-Aid for Scientific Research (Grant Number C-17530188 and C-20530188). An earlier version of this article was circulated under the title "A cohort analysis of male and female employment in Japan.”

** Corresponding author: Graduate School of Economics and Business Administration, Hokkaido University, Kita 9 Nishi 7, Kita-ku, Sapporo, 060-0809 Japan. Phone 81-11-706-3860, Fax 81-11-706-4947, Email: abey@econ.hokudai.ac.jp
} 


\section{Introduction}

Since the enactment of the Equal Employment Opportunity Law (EEOL) in 1986, many have tried to assess its impact on women's participation in the labor market in Japan (Edwards, 1988; 1994; Cannings and Lazonick, 1994). While some contend that the law has had minimal impact, recent aggregate level statistics indicate that women's participation rate has risen over time. For women aged 20-59 years, the labor force participation rate was 57.7 percent in 1980 but had risen to 68.5 percent by 2007 . Among the labor force aged 20-59 years, the proportion of women was 38.6 percent in 1980 but rose to 42.1 percent in $2007 .{ }^{1}$ Almost no studies to date have examined the long-term impact of the EEOL on women's participation in the labor market. In this article, I document trends in employment of prime-aged (ages 20-54) women in Japan by tracing cohort experiences in order to understand the impact of the EEOL on women's participation over the life cycle. ${ }^{2}$ Cohort analysis is especially useful for understanding the long-term impact of the EEOL: how did the employment

${ }^{1}$ The numbers here are based on the Labour Force Survey from 1980 and 2007 (Ministry of Internal Affairs and Communications of Japan).

2 Beginning in 1986, the EEOL prohibited discrimination against women in hiring, training, and promotion, but the law at that time asked employers to comply voluntarily. The revised law in 1999 explicitly prohibited discrimination. The EEOL was further enhanced in 2007, when discrimination against both sexes was prohibited; before 2007, only discrimination against women was prohibited. 
experiences of cohorts of women who entered the labor market in the era when the EEOL was in effect (post-EEOL cohorts) differ from those of cohorts preceding them (pre-EEOL cohorts)? ${ }^{3}$

The two major contributions of this article are as follows. First, repeated cross-sectional data of the Employment Status Survey (ESS, Shugyo Kozo Kihon Chosa) from 1987 to 2007 are used to analyze the labor force experiences of women, paying attention to (1) differences in cohort experiences in participation in regular full-time work and part-time work, (2) differences in participation by educational attainment, and (3) differences in participation by marital status. Distinguishing regular full-time work and part-time work is quite important, especially in light of the recent concerns over the part-time/full-time wage gap and the rising income inequality in Japan (Houseman and Osawa, 2003; Ohtake, 2005; Fukawa and Oshio, 2007). Second, the impact of the EEOL is assessed by controlling for macroeconomic effects. The time period I study includes Japan's prolonged economic stagnation, and teasing out the effects of the EEOL from such significant macroeconomic effects represents a considerable challenge. I account for the macroeconomic effects by using the

\footnotetext{
${ }^{3}$ The impact of the EEOL can be assessed in several different ways (e.g., wages, promotions, occupational distribution), but I focus on employment in this article.
} 
“counterfactual analysis” (see Section 6) as well as comparing the female statistics to the male statistics during the same time period.

I find that the proportion of those who work in regular full-time jobs increased after the EEOL, mainly for highly-educated women younger than age 40. Examined separately by marital status, however, post-EEOL cohorts are no more likely to work in regular full-time jobs than pre-EEOL cohorts of the same marital status and age. After the EEOL was enacted, neither married women's regular employment nor single women's regular employment advanced, and the marriage rate fell for female university graduates, for whom participation in regular employment rose.

This article is organized as follows. In the next section, I provide a brief discussion of the background. Section 3 explains the data and introduces definitions. Section 4 reports raw tabulations using aggregate data from 1987 to 2007. Section 5 reports the results disaggregated by marital status. Section 6 reports the results from the counterfactual analysis to control for the rise in educational attainment and the fall in marriage rates. Section 7 concludes.

\section{Background}

Numerous studies have analyzed women's participation in the labor market in 
Japan using cross-sectional data (e.g., Ogawa and Ermisch, 1996; Nagase, 1997; Sasaki, 2002; Nawata and Ii, 2004). However, studies based on cross-sectional data from a single point in time cannot address the questions of how the EEOL has affected women's work over the life cycle. Previous studies that conducted cohort-based analyses of labor force participation by women include Abe (2001) and Fukuda (2006). ${ }^{4}$ Abe (2001) uses cohort data from the repeated cross-sectional data of the ESS from 1982 to 1997 to study the determinants of women's participation in paid employment. Fukuda (2006) uses annual data from 1968 to 2004 to decompose female labor force participation rates into cohort, age, and time effects by employing a Bayesian framework. The data used by Abe (2001) and Fukuda (2006) do not distinguish at least one of the following aspects: (1) employment status (regular or part-time), (2) educational attainment, and (3) marital status. In this article, I report the participation patterns disaggregated by employment status (regular or part-time) for the cells defined by birth year, education, age, and marital status. The analysis reveals patterns that have not been seen in previous studies. Most notably, the proportion of

\footnotetext{
${ }^{4}$ In analyzing the development of female-male wage convergence, Kawaguchi and Naito (2006) tabulate the full-time employment ratio and estimate cross-sectional regressions to predict full-time employment for men and women using the ESS data from 1987 to 2002. Their analysis, however, is not based on cohorts.
} 
married women who work as regular employees did not rise for more recent cohorts, when it is examined separately by educational attainment. These trends are occurring in spite of the fact that the EEOL took effect in 1986, the Maternity Leave Law took effect in 1992, and women's participation in the labor market has increased over time. While the causes of the increases in married women's labor force participation have been one of the major topics in the U.S. literature (Goldin, 1990; Pencavel, 1998; Blau and Kahn, 2007), the rise in married women's employment in Japan, examined separately for education groups, predominantly consists of part-time work, not regular full-time work.

\section{Data and definitions}

The data used in this article are from the ESS, which is a large scale cross-sectional survey. ${ }^{5}$ Two different sets of data from the ESS are used: the aggregate published data and the resampled microdata. ${ }^{6}$ The published data are

\footnotetext{
${ }^{5}$ The ESS is conducted every 5 years by the Ministry of Internal Affairs and Communications of Japan. In 2002, the survey was conducted for adults in 440,000 households; the size of the original sample was 1.05 million persons aged 15 and over.

${ }^{6}$ The published tables of the aggregated data provide estimates of population by sex, age group, education, and labor force status. The data for years 1997 to 2007 are available at http://www.stat.go.jp/data/.
} 
available for five points in time from 1987 to 2007 (5-year intervals), which allows me to assess the cohort experience over 20 years. ${ }^{7}$ The microdata enable me to examine the pattern by marital status but are available only for three points in time from 1992 to 2002. ${ }^{8}$ Using the published data and the cell-mean data created from microdata, it is possible to construct pseudo-panel data that follow cohorts defined by birth year and education. ${ }^{9}$ In order to confine attention to those who finished schooling and are below the mandatory retirement age, the analysis here uses a sample of women aged 20-54 (for university graduates, aged 25-54).

${ }^{7}$ A study by Kato (2001) uses the aggregate data of ESS to examine the retention rates of Japanese employees.

${ }^{8}$ Disaggregation by marital status is not possible in the published data because labor force status statistics by education-age-marital status are not contained in the published tables. The ESS was conducted before 1987 as well, but for those years, published tables do not report the disaggregation by employment status (regular vs. part-time), age, and education. For that reason, I do not use them in this article.

${ }^{9}$ Until the 2002 ESS, respondents were asked to indicate their level of completed education by choosing one of the following four categories: junior high school graduate (9 years of compulsory schooling), senior high school graduate (12 years of schooling), junior college graduate (usually 14 years of schooling, including some vocational and technical schools), and university graduate (16 years or more of schooling, including graduate education). The format of the question on educational attainment changed in the 2007 survey, but I use the pre-2002 definition so that the cohorts defined by educational attainment can be followed. Details of the coding on the education variable are explained in the Data Appendix. 
Two measures are used for gauging participation in the labor market: the regular employment ratio and the part-time employment ratio. In Japan, employment as a regular full-time employee and employment as a non-regular employee (typically, a part-time worker) are quite different in terms of wages, hours, fringe benefits, and working conditions (Ogawa and Ermisch, 1996; Houseman and Osawa, 2003). Therefore, the regular (full-time) employment ratio and the part-time employment ratio are examined separately. Furthermore, unlike most previous research, I include executives of private corporations in the set of regular employees because many of them are promoted to the position from regular employees. ${ }^{10}$ The regular employment ratio (RER) and part-time employment ratio (PTER) are defined as follows:

$$
\begin{aligned}
R E R & =\frac{\text { Number of Regular Employees }}{\text { Population }}, \\
P T E R & =\frac{\text { Number of Part-time Employees }}{\text { Population }},
\end{aligned}
$$

where the "Number of Regular Employees" is the sum of regular employees and executives and the "Population" is the population for each cell defined by birth-year, education, and age group. ${ }^{11}$ The age group is defined in 5-year intervals (i.e., 20-24,

\footnotetext{
${ }^{10}$ See the Data Appendix for issues concerning this treatment.

${ }^{11}$ Part-time workers in the numerator of equation (2) include both part-timers and casual workers in the ESS (casual workers are referred as arbeit workers in the ESS questionnaire). Part-time workers in the ESS correspond to those who are called part-timers in the workplace. Therefore,
} 
25-29, and so on) in the published versions of the ESS, so age and birth year are grouped by 5 -year intervals. ${ }^{12}$ Note that the two measures above are calculated as shares of the population in each cell, so the denominator includes non-workers. These measures are derived for those who finished schooling; those who are in school are excluded both from the numerator and from the denominator. ${ }^{13}$

The analyses below are done separately for the four education groups. It is important to note that the educational attainment of the population has improved for more recent cohorts. The pattern of this change is shown in Table A1. The proportion of junior high school graduates is 42 percent for women born from 1938 to 1942, while it is less than 5 percent for women born from 1973 to 1977. The proportion of university graduates increased for recent cohorts: it was around 12 percent for cohorts born between 1958 and 1967 but rose to 20 percent for the 1973-77 cohort.

Inter-cohort comparison of participation in the labor market is the main focus of this article. Cohorts born in 1963 or after are the ones for whom the EEOL was in they include non-regular employees whose working hours are relatively long.

12 I use 5-year intervals for defining age groups because aggregate data spanning 1987 to 2007 are only available in 5-year intervals for age.

13 Because (potential) university graduates are still in school at ages 20-24, I have omitted observations of the age 20-24 category from the university graduate sample. 
effect at the time they finished their 4-year university education, and I refer to those women as post-EEOL cohorts. ${ }^{14}$ The age intervals of each cohort in calendar years from 1978 to 2007 are shown in Figure 1.

\section{Cohort patterns of participation behavior: aggregate data from 1987 to 2007}

In this section, patterns of cohort experiences of women's labor force behavior are shown as simple tabulations of cohort profiles, using the aggregate data from 1987 to 2007. The cohort profiles are drawn for three labor force measures (the employment-population ratio, regular employment ratio, and part-time employment ratio), separately for the level of education.

\subsection{Raw tabulations of the E-P ratio}

It is well known that the female labor force participation profile in Japan is M-shaped in a cross section. It is also commonly understood that the dip in the middle is deeper in Japan than in other developed countries (Nakamura and Ueda, 1999; Abe

\footnotetext{
${ }^{14}$ For educational groups other than university, the birth years of those who finished schooling in 1986 (the year of EEOL enactment) are 2-7 years later than those of university graduates who graduated in that year. However, because cohorts are defined by 5-year intervals, post-EEOL cohorts are approximately in the same birth year group for university, junior college, and senior high school graduates.
} 
and Oishi, 2007). Figure 2 shows the age profile of the employment-population ratio (E-P ratio) from the ESS data in 1987 and 2007, separately for each education level, for ages 20-54 (for university graduates ages 25-54). ${ }^{15}$ The cross-sectional profiles of the E-P ratio are not quite M-shaped because teens are not included, but it is clear that the ratio falls in the early 30 s and rises in the 40 s.

\subsection{Raw tabulations of the regular employment ratios}

Cohort profiles for women's participation measures are shown in Figure 3 for senior high school and university graduates, the groups that are the main focus of the subsequent analysis. ${ }^{16}$ To clarify cohort differences, I only include selected cohorts in the figures.

Figure 3 indicates that the regular employment ratios are much higher for university graduates than for senior high school graduates. The regular employment ratios for the cohorts of university graduate women born after 1963 have increased for

\footnotetext{
${ }^{15}$ In the ESS data, labor force participation status (especially unemployment) is not directly surveyed. Therefore, I use the E-P ratio here.

${ }^{16}$ The figures for all four education groups are contained in the working paper version of this article. The patterns for junior college graduates are generally similar to those of senior high school graduates.
} 
those younger than age 40. For university graduate women born between 1963 and 1972, the regular employment ratio at ages $25-29$ was 0.63 , while the same ratio at the same ages for the university graduate cohort born between 1958 and 1962 was 0.51 . However, the increase in regular employment for post-EEOL cohorts seems to have disappeared around age 40. The regular employment ratio of university graduates of the earliest post-EEOL cohort (born from 1963 to 1967) at ages 40-44 is at the same level as the previous cohorts of female university graduates.

The cohort profiles of regular employment for ages 40-54 are flat, implying that net reentry into the labor market after interruptions (due to childbirth or child rearing) does not take place as regular employment. The "flat" portion starts at ages 35-39 for senior high school graduates, while it starts at ages 40-44 for university graduates. Although the regular employment ratio for women falls until around age 40, it is likely that those who continue regular employment to that age continue working as regular employees until their mid-50s. The level of the regular employment ratio of these flat parts stays constant for cohorts born between 1948 and 1967. Finally, the cohorts who finished schooling after the late 1990s experienced a large decline in regular employment, but the fall is larger in magnitude for senior high school graduates than for university graduates. 
Figure 3 provides the inter-cohort comparison of women by comparing profiles of different birth cohorts. Such inter-cohort comparisons could be affected by macroeconomic conditions each cohort faced, as well as by the introduction of the EEOL. This concern is particularly relevant since the Japanese economy went through large business cycle fluctuations between 1987 and 2007. To address this issue, I examine whether women's regular employment rose relative to men's regular employment. Specifically, define a measure of women's regular employment relative to men, as follows:

$$
R E R_{-} \text {Ratio }=\frac{R E R_{\text {female }}}{R E R_{\text {male }}} .
$$

The $R E R \_$ratio is calculated for each cell defined by education and age group. Figure 4 plots the development of the RER_ratio for cohorts of senior high school and university graduates. While the RER_ratio rose for university graduates, it did not rise for senior high school graduates. These patterns are also confirmed quantitatively from regressions that control for age effects; the results are reported in Appendix B.

The regular employment ratio increased for university graduate women of post-EEOL cohorts, compared with their male counterparts. University graduates are the only education group that experienced such an increase relative to men. For other 
education groups, the RER_ratio did not rise. ${ }^{17}$ Therefore, the inter-cohort rise in the regular employment ratio for post-EEOL cohorts of university graduate women is robust because it occurred relative to men and not only as a comparison to pre-EEOL cohorts of women. It can also be concluded that the rise in regular employment for university graduates occurred even after controlling for macroecnomic effects.

\subsection{Raw tabulations of the part-time employment ratio}

The part-time employment ratio profiles for women are shown in Figure 5. The most notable fact is the clear cohort effects in part-time profiles. Later cohorts are much more likely to engage in part-time work, compared with previous cohorts, for all education groups. The increase in part-time work occurs in middle age, as it is a typical form of reentry into the labor market for middle-aged women. It is clear that the second peak of the M-shaped E-P ratio in Figure 2 is produced by the combination of the flat regular employment profile and the rising part-time employment profile. ${ }^{18}$

University graduate women are much less likely to work as part-timers than

\footnotetext{
17 It even fell slightly for junior high school graduates: see Table B1.

18 Age discrimination in hiring was prohibited from 2007, except in cases in which there are rational reasons for setting an age limit. It is too early to discern whether these changes in age discrimination in hiring affected women's reentry into regular employment.
} 
senior high school graduates, which is in line with the previous literature (Nagase, 1997). It has been commonly understood that female university graduates have two distinct patterns of labor force participation: a persistent participation in paid employment or a complete exit from the labor market after marriage or childbirth (Higuchi, 1991; Wakisaka and Tomita, 2001). Nonetheless, part-time work has become prevalent among university graduate women in middle age.

As shown in Figure 5, part-time employment increased steadily from 1987 to 2007, without clear distinctions between pre- and post-EEOL cohorts. This is not surprising because the EEOL is intended to promote equal opportunity in employment for men and women, while part-time jobs have been female-dominated and, thus, there is not much room for "equal opportunity" to play a role. In the rest of this article, I focus on regular employment because the role of the EEOL is more important for regular employment than for part-time employment. ${ }^{19}$

\section{Disaggregated data by marital status from 1992 to 2002}

The published data used in the last section are not disaggregated by marital status. For the years 1992, 1997, and 2002, the resampled microdata sets are available,

\footnotetext{
${ }^{19}$ The male-to-female comparison as in Eq. (3) is not suited for the part-time employment ratios, because the ratios for men are much lower than those for women.
} 
which makes it possible to obtain participation measures by marital status in addition to disaggregation by sex, age, and education. Disaggregation by marital status reveals that participation behavior differs significantly between the married and the unmarried. Furthermore, disaggregation allows me to analyze changes in regular employment around the time of marriage.

\subsection{Raw tabulations}

Figure 6 shows the participation patterns in regular employment by marital status for senior high school and university graduate women. For married women of both education groups, the regular employment ratios fall slightly for recent cohorts. For single women, the inter-cohort patterns differ across the two education groups. For senior high school graduate single women, the regular employment ratios fall uniformly for later cohorts. For university graduate single women, the regular employment ratios of post-EEOL cohorts are at levels similar to those of pre-EEOL cohorts. In sum, when disaggregated by marital status, the increase in regular employment for post-EEOL cohorts compared with pre-EEOL cohorts is not observed.

This fact suggests the following interpretation for the increase in regular employment for post-EEOL cohorts of university graduate women below age 40 (Figure 3): the EEOL did not advance regular employment of married female 
university graduates, nor did it increase regular employment of single female university graduates. The increase in women's regular employment below age 40 occurred because more university-educated women delayed marriage or chose not to marry and continued to work as regular employees.

\subsection{Regression results for regular employment by marital status}

Next, regression results using the data disaggregated by marital status are reported, for the four education groups. The regressions are estimated by a two-step procedure; the first step is to calculate participation measures for cells defined by cohort, age, education, and marital status and the second step is to relate the cell-level participation measures to explanatory variables (age and cohort dummies). ${ }^{20}$ The cell-mean observations are weighted by the inverse sampling variance of the participation measures. $^{21}$ The age and cohort dummy specification explains more than 95 percent of the variation in data, except for university graduate women.

\footnotetext{
20 This type of two-step estimation procedure is used in Card and Krueger (1992) and Card and Lemieux (2001). The grouped-data estimation is used widely in analyzing labor supply behavior (e.g., Angrist, 1991; Blundell et al., 1998; Pencavel, 1998, 2002; Devereux, 2004; Blau and Kahn, 2007).

21 The regression sample is restricted to cohorts for which at least two observations per cohort are available. Because of this, the 1973-77 cohort is not included for the university sample.
} 
Table 1 reports the regression results for women's regular employment by marital status and reveals notable differences. A dummy for the cohort born from 1973 to 1977 has a statistically significant negative impact for single women who are not university graduates. However, the decline for this cohort is much smaller for married women. For recent cohorts of less-educated single women, regular employment fell significantly (columns (2), (4), and (6)). ${ }^{22}$ The coefficients of cohort dummies for the regressions of married university graduate women (column (7)) indicate that the regular employment ratio did not increase for post-EEOL cohorts; as suggested by Figure 6, the regular employment ratios of married university graduate women are stable across age and across cohorts (pre- and post-EEOL). For married women of junior high school or senior high school graduates, the coefficients of cohort dummies decline continuously for recent cohorts.

The overall pattern of women's regular employment shows that the EEOL did not advance married women's regular employment, nor did it advance single women’s regular employment. After the enactment of the EEOL, the composition of marital status among female university graduates changed. The impact of the falling marriage

\footnotetext{
${ }^{22}$ It might have been expected that the EEOL would increase single women's regular employment if it diminished the degree of discrimination against women in the workplace. In reality, this effect was not observed.
} 
rate is explored in subsection 6.2.

There are two possible interpretations of this concurrence of the EEOL and the fall in marriage. One is that since it is difficult for women to balance career and family in Japan and career opportunities broadened after the enactment of the EEOL, women of post-EEOL cohorts postponed marriage compared with their pre-EEOL counterparts. Another interpretation would be that after the enactment of the EEOL, more women obtained regular jobs and were too busy at work to find their future partners.

\section{Role of educational and marital status composition}

In this section, I examine the possible influence of educational choice and marital status on the regular employment ratios of women. The educational and marital choices of women changed during the time period I analyze in this article. As Table A1 shows, the proportion of women obtaining a 4-year university education was 13 percent for cohorts born from 1958 to 1962, while the same proportion was 20 percent for those born from 1973 to 1977 . The introduction of the EEOL might have made it worthwhile for women to obtain more education (Edwards and Pasquale, 2003).

Marriage rates have been falling over time: among university graduate women, the proportion of married people at ages 30-34 was 74.8 percent for the 1958-62 birth 
cohort, while it was 61.5 percent for the 1968-72 birth cohort. In the following subsections, the impact of these changes on the regular employment ratio is assessed quantitatively by comparing the counterfactual $R E R$ and actual $R E R$.

The counterfactual $R E R$ is derived under the assumption that the regular employment ratio is set equal to the level of a post-EEOL cohort but the educational or marital composition is equal the pre-EEOL figures. The difference between the actual and counterfactual RERs measures the impact of compositional change in education or marriage. In this way, I effectively set the macroeconomic conditions constant across cohorts (pre- and post-EEOL). Since the data for post-EEOL cohorts are limited to young ages, I compare them with the latest pre-EEOL cohorts (born from 1953 to 1957 and from 1958 to 1962).

\subsection{Role of educational composition}

In my data, the educational composition of cohorts becomes stable only after age 25; thus, I am only able to compare the cohorts born before $1977 .^{23}$ The counterfactual regular employment ratio, $\widehat{R E R_{c^{\prime}, c}}$, is defined as follows:

$$
\widehat{R E R_{c^{\prime}, c}}=\sum_{s} \phi_{s c^{\prime}} \cdot R E R_{s c}
$$

\footnotetext{
${ }^{23}$ Note that I work with cell-mean data where age groups are defined in 5-year intervals. At ages 20-24, many potential university graduates are still in school.
} 
where $s$ is the index of schooling, $c$ and $c^{\prime}$ are the indices for birth year, and $\phi_{s c^{\prime}}$ is the share of people whose education is $s$ for cohort $c^{\prime} . \widehat{R E R_{c^{\prime}, c}}$ is the level of the regular employment ratio for cohort $c$ that would have prevailed if the educational composition were that of cohort $c^{\prime}$ but the regular employment ratio is that of cohort $c$; $c$ is set to one of the post-EEOL cohorts and $c^{\prime}$ is set to one of the pre-EEOL cohorts. The difference between $R E R_{c}$ and $\widehat{R E R_{c^{\prime}, c}}$ measures how much of the increase in regular employment is attained by educational advancement. The counterfactual and actual RERs and their difference are shown in Table 2.

The educational composition started to improve for cohorts born after 1968 but not for those born from 1963 to 1967 (Table A1). ${ }^{24}$ As a result, the impact of educational advancement is small for the 1963-67 cohort: less than 3 percentage points in all comparisons shown in Table 2. On the other hand, educational advancement increased the regular employment ratio of the 1973-77 cohort by 3-6 percentage points.

\footnotetext{
${ }^{24}$ The cohort born from 1963 to 1967 might have made their higher education decisions before the passage of the EEOL in 1985, which may explain why their educational attainment did not increase from that of the previous cohorts. In that sense, it may seem inappropriate to regard them as a post-EEOL cohort. Nonetheless, I designate them as a post-EEOL cohort since their marriage and regular employment experiences differ markedly from previous cohorts.
} 
6.2. Role of the marriage rate for university graduates

Next, the impact of the marriage rate for university graduates is analyzed. ${ }^{25}$ I calculate the counterfactual regular employment ratio of the post-EEOL cohorts, the level of the regular employment ratio that would have prevailed if the marriage rate were equal to that of the earlier cohort (the 1958-62 birth cohort or the 1963-67 birth cohort, depending on the age group). If the marriage rate played a significant role, then the difference between the counterfactual and the actual regular employment ratio would be large. The counterfactual regular employment ratio for the marriage rate is defined as

$$
\widehat{R E R_{U, c^{\prime}, c}}=m_{c^{\prime}} \cdot R E R_{U, m, c}+\left(1-m_{c^{\prime}}\right) \cdot R E R_{U, s, c}
$$

where $c^{\prime}$ is the index for the earlier cohort, $c$ is the index for a post-EEOL cohort, $m_{c^{\prime}}$ is the marriage rate of cohort $c^{\prime}$, and $R E R_{U, j, c}$ is the regular employment ratio of university graduate women of cohort $c$ and marital status $j(j=M, S)$; the subscript $U$ is added to show that they are calculated for university graduates. The counterfactual and actual regular employment ratios for university graduates are shown in Table 3; for purposes of comparison, actual regular employment ratios for married

25 The marriage rate has been falling for other education groups as well. I focus attention on university graduate women here because this is the only group for which the regular employment ratio does not fall significantly across cohorts when regressions are estimated by marital status (Table 1). 
and single women are also shown.

It is evident from Table 3 that the regular employment ratio would have been lower had the marriage rate remained at the level of the 1958-62 birth cohort. The fall in the marriage rate raises the regular employment ratio for all women (married plus single) by 2-4 percentage points. Even for the cohorts that did not differ in educational attainment (the 1958-62 and the 1963-67 birth cohort), the marital status composition changed, and consequently, the regular employment ratio changed.

In summary, educational advancement did not take place for the cohort born from 1963 to 1967, the earliest post-EEOL cohort. The marriage rate, however, fell for this cohort compared with the 1958-62 cohort. I conclude that the EEOL affected marriage and employment behaviors of post-EEOL cohorts, even those of the earliest cohort who had already made their higher education decisions at the time of the law's passage. For the later cohorts, education, employment, and marriage decisions changed.

\section{Conclusions}

In this article, I use repeated cross-sectional data to examine the impact of the EEOL on women's employment for the period from 1987 to 2007. The analysis by marital status reveals that the increase in regular employment for university graduate 
women at young ages is the result of a delay or decline in marriage. The regular employment ratio did not go up for either married or single women of post-EEOL cohorts (cohorts who entered the labor market after the EEOL). For educational groups other than university graduates, the regular employment ratio for post-EEOL cohort single women actually fell. ${ }^{26}$

Since the enactment of the EEOL, more women with university education have married late or stayed unmarried. Because the regular employment ratio is much higher for single women than it is for married women, the increase in single women in the population resulted in an increase in the regular employment ratios for all women, mainly for those younger than age 40 .

\section{Appendix A: Educational composition}

The educational composition of each birth cohort is shown in Table A1. The figures are derived from the ESS in 2002. Data from other years show similar patterns of educational distribution for each cohort.

\footnotetext{
${ }^{26}$ Edwards (1988) predicted that the Japanese EEOL would not have much effect in advancing the economic status of women. The results presented in this article may, at least partially, be consistent with that prediction.
} 


\section{Appendix B: Controlling for macroeconomic effects}

In Figure 4, the ratio of female-to-male RER is tabulated to assess the roles of macroeconomic factors. To understand the patterns quantitatively, I regress the $R E R \_$ratio on age and cohort dummies. Table B1 reports the results. ${ }^{27}$

The inter-cohort improvement in the gender employment ratio differs across education groups. University graduates of post-EEOL cohorts (born after 1963) are the only ones that experienced a robust increase in $R E R$ relative to men with the same education; the coefficients on cohort dummies for this group are positive (between 0.05 and 0.1) and are statistically significant. For junior high school graduates of post-EEOL cohorts, the coefficients are negative, which means that women of this education group lost regular employment relative to men with the same education. For senior high school and junior college graduates, most coefficients of cohort dummies are small in magnitude and are statistically insignificant, implying that RERs of women did not change much relative to their male counterparts. Therefore, for senior high school and junior college graduates, the loss in regular employment for cohorts born

\footnotetext{
${ }^{27}$ Regression results that use a slightly different dependent variable and the same independent variables are reported in Table 3 of Abe (2010); the estimates are the same as in Table B1, except for signs. In that article, the main focus is to understand the convergence in regular employment ratios across genders.
} 
from 1973 to 1982 may be attributed to business cycle factors.

\section{Data Appendix}

\section{(1) Coding of the education variable in the 2007 ESS}

The coding of the education variable is different in the 2007 ESS from surveys of earlier years (1987, 1992, 1997, and 2002). Two major changes in the 2007 survey are as follows: (1) the education group that used to be the combined group of “University or more” was separated into "University” and “Graduate school,” and (2) "Vocational school” was added in the 2007 survey, although such a category did not exist in previous surveys. For (1), I summed up the data of the population and the number of workers for university and graduate school in the 2007 data so that the coding is consistent for the same birth cohort across survey years. For (2), there is no obvious solution because those who would have answered "Vocational school" in 2007 could have identified themselves as either "Senior high school graduate" or "Junior college graduate” to the survey questionnaire before 2002. I experimented with several procedures to assign an education code and compared the distribution of educational attainment of the same cohort across the 5 years of data (from 1987 to 2007). Assigning "Vocational school" in 2007 to the "Junior college" category seems to yield 
a relatively consistent educational distribution across years, so I use it in the analysis reported in this article.

\section{(2) Inclusion of executives in the number of regular employees ${ }^{28}$}

In this study, the regular employment ratios are calculated differently from those in previous studies. The procedures and related issues are explained below.

In the numerator of Eq. (1) in the text, the executives of private corporations are included. The inclusion of executives in the regular employment category has certain implications. If the numerator of the regular employment ratio does not include executives, the ratio falls significantly with age for university graduate men and women aged 40 and over. When executives are included in the numerator, however, the fall is small or nonexistent. Furthermore, disparities across educational groups are larger for the measure that includes executives because the proportion of executives in the population is much higher for university graduates than for other education groups, especially for men.

\footnotetext{
${ }^{28}$ Although this article is mostly concerned with women's employment and not with men's, inclusion of executives in the regular employees has a pronounced effect on men's regular employment ratios. Therefore, some of the explanations in this Appendix are concerned with data on men.
} 
To obtain the regular employment ratio in 1992 and 1997, I use resampled microdata because the number of executives is not reported in the published tables for these years.

\section{References}

Abe, Masahiro. (2001) “Jyosei no Rodo Kyokyu to Sedai Koka” [Women’s Labor Supply and Cohort Effect], In: Wakisaka, A., and Y. Tomita, eds. Daisotsu Josei no Hatarakikara [Work Decisions by College Graduate Women] (in Japanese).

Abe, Yukiko. (2010). "Equal Employment Opportunity Law and the gender wage gap in Japan: A cohort analysis.” Journal of Asian Economics 21, 142-155.

Abe, Yukiko, and Akiko S. Oishi. (2007) “The Role of Married Women's Labor Supply on Family Earnings Distribution in Japan.” Journal of Income Distribution 16, 110-127.

Angrist, Joshua D. (1991) “Grouped-data estimation and testing in simple labor-supply models.” Journal of Econometrics 47, 243-266.

Blau, Francine D. and Lawrence M. Kahn. (2007) “Changes in the Labor Supply Behavior of Married Women: 1980-2000.” Journal of Labor Economics 25:3, 393-438.

Blundell, Richard, Duncan, Alan, and Costas Meghir. (1998) “Estimating Labor 
Supply Responses Using Tax Reforms.” Econometrica 66:4, 827-61.

Cannings, Kathleen and William Lazonick. (1994) “Equal Employment Opportunity and the "Managerial Women” in Japan.” Industrial Relations 33:1, 44-69.

Card, David, and Alan B. Krueger. (1992) “Does School Quality Matter? Returns to Education and the Characteristics of Public Schools in the United States.” Journal of Political Economy 100:1, 1-40.

Card, David, and Thomas Lemieux. (2001) "Can Falling Supply Explain the Rising Return to College for Younger Men? A Cohort-based Analysis.” Quarterly Journal of Economics 705-746.

Devereux, Paul J. (2004) “Changes in Relative Wages and Family Labor Supply.” Journal of Human Resources 39:3 696-722.

Edwards, Linda N. (1988) “Equal Employment Opportunity in Japan: A View from the West.” Industrial and Labor Relations Review 41:2, 240-250.

Edwards, Linda N. (1994) “The Status of Women in Japan: Has the Equal Employment Opportunity Law Made a difference?” Journal of Asian Economics 5:2, 217-240.

Edwards, Linda N. and Margaret K. Pasquale. (2003) “Women’s higher education in Japan: Family background, economic factors, and the Equal Employment Opportunity Law.” Journal of the Japanese and International Economies 17, 1-32. 
Fukuda, Kosei. (2006) “A Cohort Analysis of Female Labor Participation Rates in the U.S. and Japan.” Review of Economics of the Household 3, 379-393.

Fukawa, Tetsuo, and Takashi Oshio. (2007) "Income Inequality Trends and Their Challenges to Redistribution Policies in Japan.” Journal of Income Distribution 16, 9-30.

Goldin, Claudia. (1990) Understanding the Gender Gap: An Economic History of American Women. Oxford University Press.

Higuchi, Yoshio. (1991) Nihon Keizai to Shugyo Kodo [Japanese Economy and Work Behavior] Toyo Keizai Shimpo Sha, Tokyo (in Japanese).

Houseman, Susan, and Machiko Osawa. (2003) "The Growth of Nonstandard Employment in Japan and the United States: Comparison of Causes and Consequences.” In: Houseman, S., and M. Osawa, eds, Nonstandard Work in Developed Economies, W.E. Upjohn Institute for Employment Research, Kalamazoo, Michigan, pp. 175-214.

Kato, Takao. (2001) “The End of Lifetime Employment in Japan?: Evidence from National Surveys and Field Research.” Journal of the Japanese and International Economies, 15, 489-514.

Kawaguchi, Daiji, and Hisahiro Naito. (2006) “The Bound Estimate of the Gender 
Wage Convergence under Employment Compositional Change.” ESRI Discussion Paper 161.

Nagase, Nobuko. (1997) "Wage Differentials and Labour Supply of Married Women in Japan: Part-time and Informal Sector Work Opportunities." Japanese Economic Review 48, 29-42.

Nagase, Nobuko. (2003) “Standard and Nonstandard Work Arrangement, Pay Difference, and Choice of Work by Japanese Mothers.” In: Houseman, S., and M. Osawa, eds, Nonstandard Work in Developed Economies, W.E. Upjohn Institute for Employment Research, Kalamazoo, Michigan, pp. 267-305.

Nakamura, Jiro, and Atsuko Ueda. (1999) “On the Determinants of Career Interruption by Childbirth among Married Women in Japan.” Journal of the Japanese and International Economies 13, 73-89.

Nawata, Kazumitsu, and Masako Ii. (2004) "Estimation of the labor participation and wage equation model of Japanese married women by the simultaneous maximum likelihood method.” Journal of the Japanese and International Economies 18, 301-315.

Ogawa, Naohiro, and John F. Ermisch. (1996) "Family Structure, Home Time Demands, and the Employment Patterns of Japanese Married Women.” Journal of 
Labor Economics 14, 677-702.

Ohtake, Fumio. (2005) Nihon no Fubyoudou [Inequality in Japan]. Nihon Keizai Shinbunsha, Tokyo (in Japanese).

Pencavel, John. (1998) “The Market Work Behavior and Wages of Women: 1975-94.” Journal of Human Resources 33:4 771-804. . (2002) “A Cohort Analysis of the Association between Work Hours and Wages among Men.” Journal of Human Resources 37:4 251-274.

Sasaki, Masaru. (2002) “The Causal Effect of Family Structure on Labor Force Participation among Japanese Married Women.” Journal of Human Resources 37:2, 429-40.

Wakisaka, Akira, and Yasunobu Tomita. (2001) Daisotu Jyosei no Hatarakikata -Jyosei ga Shigoto wo Tudukerutoki, Yamerutoki- [Work Decisions of College Graduate Women: When Women continue working or stop working] Japan Institute of Labour, Tokyo (in Japanese). 
Table 1

Regression results for regular employment ratio by marital status: Women

1992-2002

\begin{tabular}{|c|c|c|c|c|c|c|c|c|}
\hline & \multicolumn{2}{|l|}{ Junior High } & \multicolumn{2}{|l|}{ Senior High } & \multicolumn{2}{|l|}{ Junior College } & \multicolumn{2}{|l|}{ University } \\
\hline & Married & Single & Married & Single & Married & Single & Married & Single \\
\hline & (1) & (2) & (3) & (4) & (5) & (6) & (7) & (8) \\
\hline Dummy for born & 0.074 ** & $0.143 * *$ & $0.041 * *$ & 0.117 * & -0.009 & 0.055 & -0.001 & 0.041 \\
\hline $1943-47$ & (0.011) & $(0.025)$ & (0.010) & (0.035) & (0.013) & $(0.033)$ & $(0.016)$ & $(0.115)$ \\
\hline Dummy for born & 0.035 * & 0.067 * & 0.020 * & 0.063 & 0.006 & 0.045 & 0.006 & 0.043 \\
\hline $1948-52$ & $(0.010)$ & $(0.022)$ & $(0.008)$ & $(0.028)$ & (0.009) & $(0.023)$ & $(0.011)$ & $(0.081)$ \\
\hline Dummy for born & $-0.056 * *$ & $-0.101 *$ & $-0.026 *$ & -0.062 & $-0.031 * *$ & -0.034 & $-0.039 *$ & 0.006 \\
\hline $1958-62$ & (0.015) & $(0.028)$ & (0.009) & $(0.030)$ & (0.008) & $(0.020)$ & (0.010) & $(0.069)$ \\
\hline Dummy for born & $-0.107 * *$ & -0.153 ** & $-0.044 * *$ & -0.121 * & $-0.053 * \star$ & $-0.101 * *$ & -0.038 * & -0.021 \\
\hline $1963-67$ & $(0.018)$ & $(0.034)$ & $(0.010)$ & (0.035) & (0.009) & $(0.023)$ & $(0.013)$ & $(0.078)$ \\
\hline $\begin{array}{l}\text { Dummy for born } \\
1968-72\end{array}$ & -0.103 ** & -0.281 ** & -0.058 ** & -0.206 ** & -0.046 ** & -0.134 ** & -0.046 * & $\begin{array}{l}-0.060 \\
(0.082)\end{array}$ \\
\hline $\begin{array}{c}\text { Dummy for born } \\
1973-77\end{array}$ & $\begin{array}{l}-0.106 \\
(0.027)\end{array}$ ** & $\begin{array}{l}-0.371 \text { ** } \\
(0.044)\end{array}$ & $\begin{array}{l}-0.055 \text { * } \\
(0.018)\end{array}$ & $\begin{array}{l}-0.335 \\
(0.039)\end{array}$ & $\begin{array}{l}-0.050 \text { * } \\
(0.015)\end{array}$ & $\begin{array}{l}-0.229 \\
(0.024)\end{array}$ & - & $(0.002)$ \\
\hline Dummy for Age 20-24 & $\begin{array}{r}0.007 \\
(0.028)\end{array}$ & $\begin{array}{l}0.376 \text { ** } \\
(0.044)\end{array}$ & $\begin{array}{r}0.028 \\
(0.021)\end{array}$ & $\begin{array}{l}0.483 \text { ** } \\
(0.038)\end{array}$ & $\begin{array}{r}0.031 \\
(0.022)\end{array}$ & $\begin{array}{c}0.381 \text { ** } \\
(0.023)\end{array}$ & - & - \\
\hline Dummy for Age 25-29 & $\begin{array}{r}-0.002 \\
(0.023)\end{array}$ & $\begin{array}{l}0.263 \text { ** } \\
(0.041)\end{array}$ & $\begin{array}{r}0.006 \\
(0.013)\end{array}$ & $\begin{array}{l}0.332 \text { ** } \\
(0.037)\end{array}$ & $\begin{array}{r}0.023 \\
(0.012)\end{array}$ & $\begin{array}{l}0.260 \text { ** } \\
(0.023)\end{array}$ & $\begin{array}{l}0.095 \text { ** } \\
(0.018)\end{array}$ & $\begin{array}{r}0.179 \\
(0.081)\end{array}$ \\
\hline Dummy for Age 30-34 & $\begin{array}{r}0.010 \\
(0.019)\end{array}$ & $\begin{array}{l}0.154 \text { ** } \\
(0.036)\end{array}$ & $\begin{array}{r}-0.018 \\
(0.010)\end{array}$ & $\begin{array}{l}0.163 \text { ** } \\
(0.034)\end{array}$ & $\begin{array}{r}-0.018 \\
(0.009)\end{array}$ & $\begin{array}{l}0.139 \\
(0.022)\end{array}$ & $\begin{array}{r}0.017 \\
(0.013)\end{array}$ & $\begin{array}{r}0.077 \\
(0.077)\end{array}$ \\
\hline Dummy for Age 35-39 & $\begin{array}{r}0.016 \\
(0.014)\end{array}$ & $\begin{array}{l}0.080 \text { * } \\
(0.028)\end{array}$ & $\begin{array}{r}-0.010 \\
(0.009)\end{array}$ & $\begin{array}{l}0.088 \text { * } \\
(0.030)\end{array}$ & $\begin{array}{r}-0.014 \\
(0.008)\end{array}$ & $\begin{array}{l}0.075 \text { ** } \\
(0.020)\end{array}$ & $\begin{array}{r}0.005 \\
(0.010)\end{array}$ & $\begin{array}{r}0.052 \\
(0.069)\end{array}$ \\
\hline Dummy for Age $45-49$ & $\begin{array}{r}-0.008 \\
(0.009)\end{array}$ & $\begin{array}{r}-0.025 \\
(0.021)\end{array}$ & $\begin{array}{r}0.001 \\
(0.008)\end{array}$ & $\begin{array}{r}-0.057 \\
(0.028)\end{array}$ & $\begin{array}{r}0.008 \\
(0.009)\end{array}$ & $\begin{array}{l}-0.066 \text { * } \\
(0.023)\end{array}$ & $\begin{array}{r}0.000 \\
(0.011)\end{array}$ & $\begin{array}{r}-0.086 \\
(0.081)\end{array}$ \\
\hline Dummy for Age 50-54 & $\begin{array}{l}-0.053 \text { ** } \\
(0.010)\end{array}$ & $\begin{array}{l}-0.086 \text { ** } \\
(0.023)\end{array}$ & $\begin{array}{l}-0.031 \text { * } \\
(0.010)\end{array}$ & $\begin{array}{l}-0.166 \text { ** } \\
(0.033)\end{array}$ & $\begin{array}{r}0.004 \\
(0.012)\end{array}$ & $\begin{array}{l}-0.122 \text { ** } \\
(0.030)\end{array}$ & $\begin{array}{r}-0.009 \\
(0.015)\end{array}$ & $\begin{array}{r}-0.051 \\
(0.107)\end{array}$ \\
\hline R-squared & 0.984 & 0.965 & 0.972 & 0.989 & 0.965 & 0.995 & 0.919 & 0.810 \\
\hline
\end{tabular}

Notes:

Sample sizes are 19 for column (1)-(6) and 16 for column (7) and (8). Standard errors are in parentheses.

All regression equations include a constant.

The base group for cohort dummies is the cohort born in 1953-57.

The base group for age dummies is those aged 40-44.

* Statistically significant at the $5 \%$ level; ** at the $1 \%$ level (two-tailed tests)

Source: ESS(resampled data) 1992-2002. 
Table 2: The role of educational composition on regular employment ratios

\begin{tabular}{|l|l|r|r|r|r|r|}
\hline Birth year interval & Age & \multicolumn{1}{|l|}{ Actual RER } & \multicolumn{1}{l|}{ Counterfactual RER } & \multicolumn{2}{l|}{ Diff } \\
\hline & & & (1) $c^{\prime}=1958-62$ & $(2) c^{\prime}=1953-57$ & $(1) c^{\prime}=1958-62$ & $(2) c^{\prime}=1953-57$ \\
\hline $1963-67$ & $25-29$ & 0.446 & 0.443 & 0.418 & 0.003 & 0.028 \\
$1968-72$ & $25-29$ & 0.454 & 0.444 & 0.416 & 0.010 & 0.038 \\
$1973-77$ & $25-29$ & 0.424 & 0.395 & 0.367 & 0.029 & 0.056 \\
\hline
\end{tabular}

\begin{tabular}{|c|c|c|c|c|c|c|}
\hline Birth year interval & Age & Actual RER & Counterfactual RER & & Diff & \\
\hline & & & (1) $c^{\prime}=1958-62$ & (2) $c^{\prime}=1953-57$ & (1) $c^{\prime}=1958-62$ & (2) $c^{\prime}=1953-57$ \\
\hline $1958-62$ & $30-34$ & 0.284 & & & & \\
\hline $1963-67$ & $30-34$ & 0.296 & 0.295 & 0.282 & 0.001 & 0.015 \\
\hline $1968-72$ & $30-34$ & 0.290 & 0.282 & 0.266 & 0.008 & 0.024 \\
\hline
\end{tabular}

\begin{tabular}{|c|c|c|c|c|c|c|}
\hline Birth year interval & Age & Actual RER & Counterfactual RER & & Diff & \\
\hline & & & (1) $c^{\prime}=1958-62$ & (2) $c^{\prime}=1953-57$ & (1) $c^{\prime}=1958-62$ & (2) $c^{\prime}=1953-57$ \\
\hline $1953-57$ & $35-39$ & 0.280 & & & & \\
\hline $1958-62$ & $35-39$ & 0.274 & & & & \\
\hline $1963-67$ & $35-39$ & 0.259 & 0.258 & 0.247 & 0.001 & 0.012 \\
\hline
\end{tabular}

Note: Diff=(Actual RER)-(Counterfactual RER)

Source: Author's calculation from ESS 1992-2002 (published data). 
Table 3: The role of marriage on university graduate women's regular employment ratios

\begin{tabular}{|c|c|c|c|c|c|c|c|}
\hline Birth year interval & Age & $\begin{array}{l}\text { Percent } \\
\text { married }\end{array}$ & Counterfactual RER & Actual RER & Diff & RER:single & RER: married \\
\hline $1963-67\left(c^{\prime}\right)$ & $25-29$ & 0.374 & & 0.627 & & 0.772 & 0.384 \\
\hline 1968-72 & $25-29$ & 0.321 & 0.609 & 0.628 & 0.020 & 0.748 & 0.377 \\
\hline 1973-77 & $25-29$ & 0.271 & 0.536 & 0.569 & 0.033 & 0.655 & 0.337 \\
\hline 1958-62 (c') & $30-34$ & 0.748 & & 0.395 & & 0.666 & 0.303 \\
\hline 1963-67 & 30-34 & 0.693 & 0.414 & 0.436 & 0.023 & 0.724 & 0.309 \\
\hline 1968-72 & $30-34$ & 0.615 & 0.380 & 0.423 & 0.043 & 0.622 & 0.298 \\
\hline $1963-67\left(c^{\prime}\right)$ & $30-34$ & 0.693 & & 0.436 & & 0.724 & 0.309 \\
\hline 1968-72 & $30-34$ & 0.615 & 0.398 & 0.423 & 0.025 & 0.622 & 0.298 \\
\hline 1958-62 (c') & $35-39$ & 0.840 & & 0.368 & & 0.751 & 0.295 \\
\hline 1963-67 & $35-39$ & 0.765 & 0.342 & 0.365 & 0.023 & 0.604 & 0.292 \\
\hline
\end{tabular}

Note: Diff=(Actual RER)-(Counterfactual RER)

Source: Author's calculation from ESS 1992-2002 (resampled data). 
Table A1: Educational distribution of women by birth year groups

\begin{tabular}{lrrrr}
\hline Birth years & Junior High & Senior High & Junior College & University \\
\hline $1938-42$ & 0.421 & 0.483 & 0.068 & 0.028 \\
$1943-47$ & 0.311 & 0.536 & 0.103 & 0.049 \\
$1948-52$ & 0.198 & 0.580 & 0.157 & 0.066 \\
$1953-57$ & 0.112 & 0.541 & 0.236 & 0.111 \\
$1958-62$ & 0.049 & 0.517 & 0.306 & 0.128 \\
$1963-67$ & 0.044 & 0.507 & 0.321 & 0.128 \\
$1968-72$ & 0.053 & 0.450 & 0.348 & 0.149 \\
$1973-77$ & 0.045 & 0.369 & 0.388 & 0.198 \\
\hline
\end{tabular}

Note: The figures are the share of population of each educational group for the birth year group. The figures are calculated for those who are over 25 years old.

Source: Employment Status Survey, 2002 
Table B1: Effects of cohort and age on RER_ratio

Dependent variable: Gap in the regular employment ratio (RER_ratio)

\begin{tabular}{|c|c|c|c|c|}
\hline & (1) & $(2)$ & (3) & (4) \\
\hline $\begin{array}{l}\text { Education level of the } \\
\text { sample }\end{array}$ & Junior High & Senior High & Junior College & University \\
\hline Dummy for born & $0.055^{\star}$ & 0.024 & $-0.050 * \star$ & -0.030 \\
\hline $1943-47$ & $(0.024)$ & $(0.016)$ & $(0.016)$ & $(0.015)$ \\
\hline Dummy for born & 0.040 & 0.022 & -0.017 & 0.004 \\
\hline 1948-52 & $(0.021)$ & $(0.017)$ & (0.011) & (0.015) \\
\hline Dummy for born & 0.030 & 0.014 & -0.008 & 0.006 \\
\hline 1953-57 & $(0.025)$ & (0.018) & (0.017) & (0.018) \\
\hline Dummy for born & -0.002 & 0.026 & -0.009 & $0.051^{*}$ \\
\hline $1963-67$ & $(0.017)$ & (0.018) & (0.013) & (0.020) \\
\hline Dummy for born & -0.024 & 0.041 & 0.022 & $0.082^{\star \star}$ \\
\hline $1968-72$ & $(0.019)$ & $(0.020)$ & $(0.017)$ & $(0.019)$ \\
\hline Dummy for born & $-0.046^{\star}$ & 0.019 & 0.020 & 0.096 *夫 \\
\hline 1973-77 & $(0.017)$ & $(0.024)$ & $(0.026)$ & $(0.022)$ \\
\hline Dummy for born & -0.102 & -0.062 & 0.056 & \\
\hline 1978-82 & $(0.049)$ & $(0.057)$ & (0.028) & \\
\hline \multirow[t]{2}{*}{ Dummy for Age 20-24 } & $0.100 * \star$ & $0.446^{\star \star}$ & $0.488^{\star \star}$ & \\
\hline & $(0.025)$ & $(0.028)$ & $(0.023)$ & \\
\hline \multirow[t]{2}{*}{ Dummy for Age 25-29 } & -0.008 & $0.115^{\star \star}$ & $0.201^{\star \star}$ & $0.190 * \star$ \\
\hline & $(0.020)$ & $(0.022)$ & $(0.017)$ & $(0.025)$ \\
\hline \multirow[t]{2}{*}{ Dummy for Age 30-34 } & $-0.051^{*}$ & -0.031 & -0.015 & 0.007 \\
\hline & $(0.021)$ & (0.018) & (0.015) & (0.019) \\
\hline \multirow[t]{2}{*}{ Dummy for Age 35-39 } & -0.030 & -0.034 & $-0.038 * \star$ & -0.012 \\
\hline & $(0.024)$ & $(0.017)$ & $(0.010)$ & (0.015) \\
\hline \multirow[t]{2}{*}{ Dummy for Age 45-49 } & 0.040 & $0.033^{*}$ & $0.028^{\star}$ & 0.021 \\
\hline & $(0.022)$ & $(0.013)$ & (0.011) & (0.013) \\
\hline \multirow[t]{2}{*}{ Dummy for Age 50-54 } & 0.002 & 0.009 & $0.064^{* *}$ & $0.043^{*}$ \\
\hline & $(0.018)$ & (0.013) & $(0.014)$ & $(0.020)$ \\
\hline \multirow{2}{*}{ Constant } & $0.301^{* *}$ & $0.307^{\star \star}$ & $0.403^{\star \star}$ & $0.404^{\star \star}$ \\
\hline & $(0.021)$ & $(0.014)$ & $(0.013)$ & $(0.013)$ \\
\hline Number of & 31 & 31 & 31 & 26 \\
\hline R-squared & 0.856 & 0.980 & 0.991 & 0.964 \\
\hline
\end{tabular}

Notes:

Robust standard errors in parentheses.

* significant at the $5 \%$ level; ${ }^{* \star}$ significant at the $1 \%$ level.

Regressions are estimated by weighted least squares, using the population in each cell as weights.

The base group for cohort dummies is the cohort born in 1958-62.

The base group for age dummies is those aged 40-44.

Source: Author's calculation from the ESS (1987-2007). 
Figure 1: Age intervals of cohorts at calender years

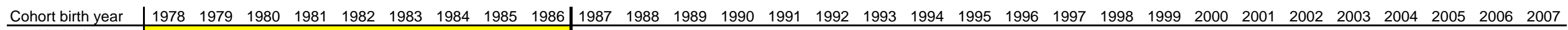

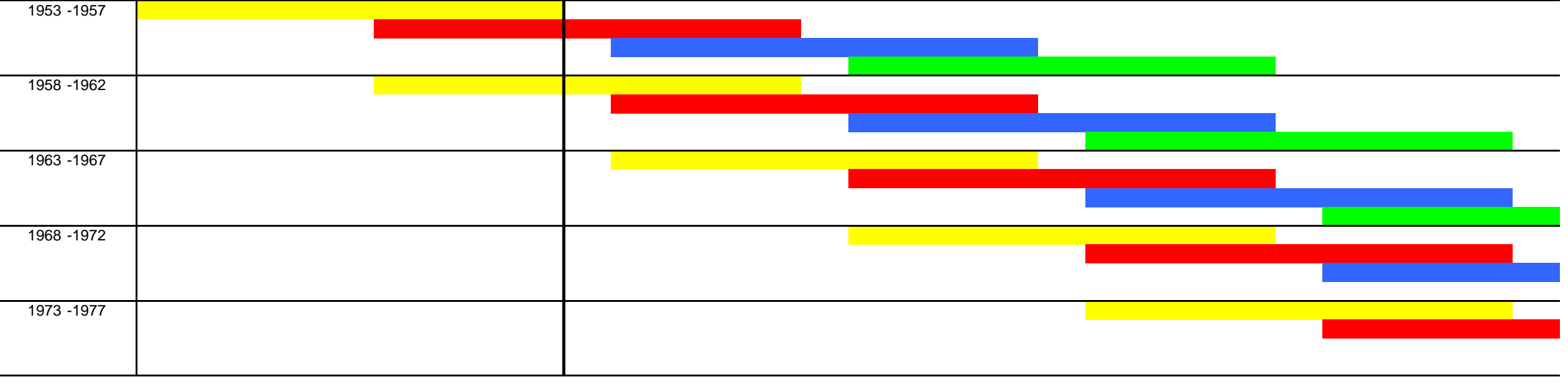

EEOL's enactment

Age intervals

25-29

30-34

35-39

40-44 
Figure 2. The cross-sectional E-P ratio of women

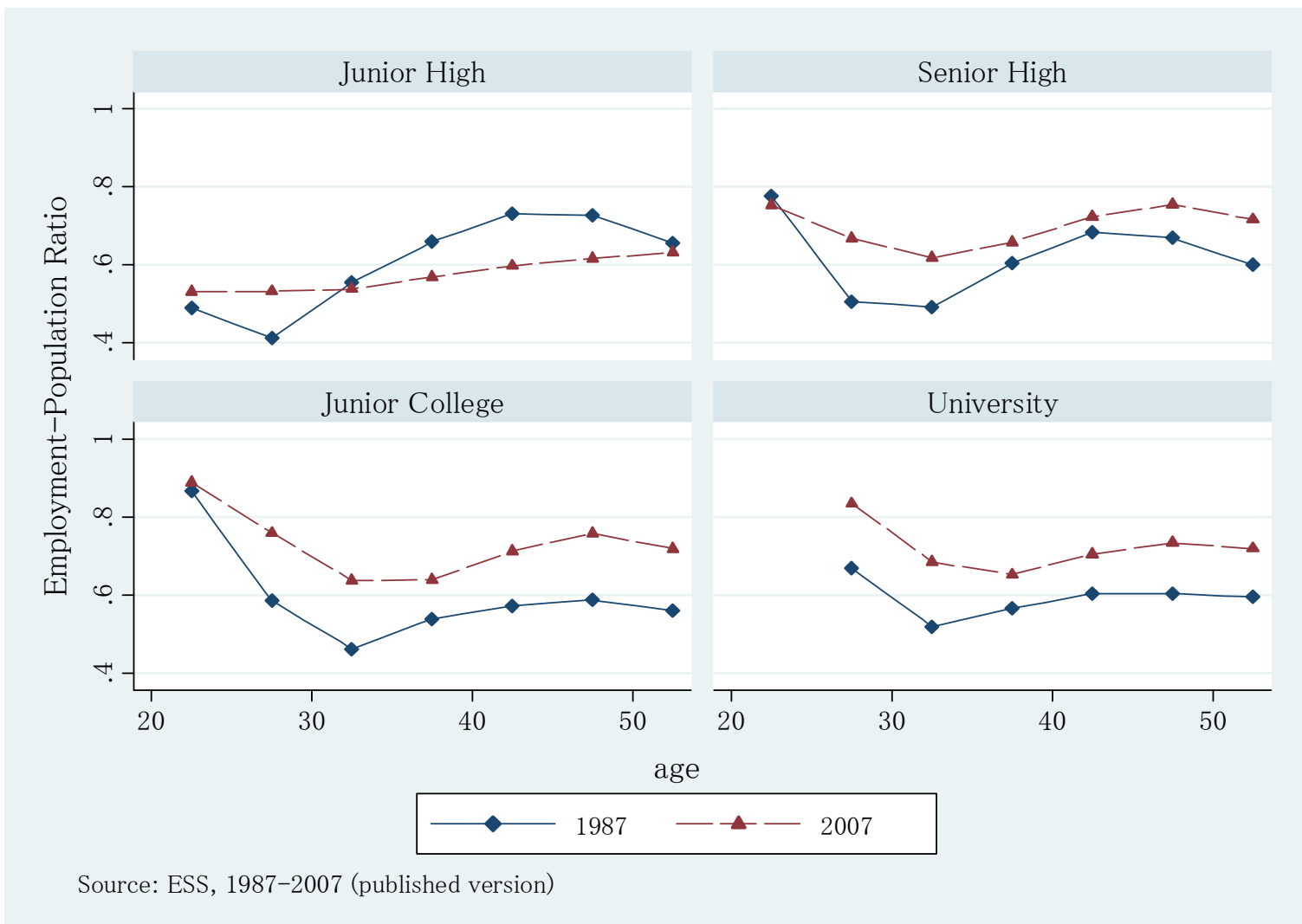


Figure 3. The regular employment ratio of women

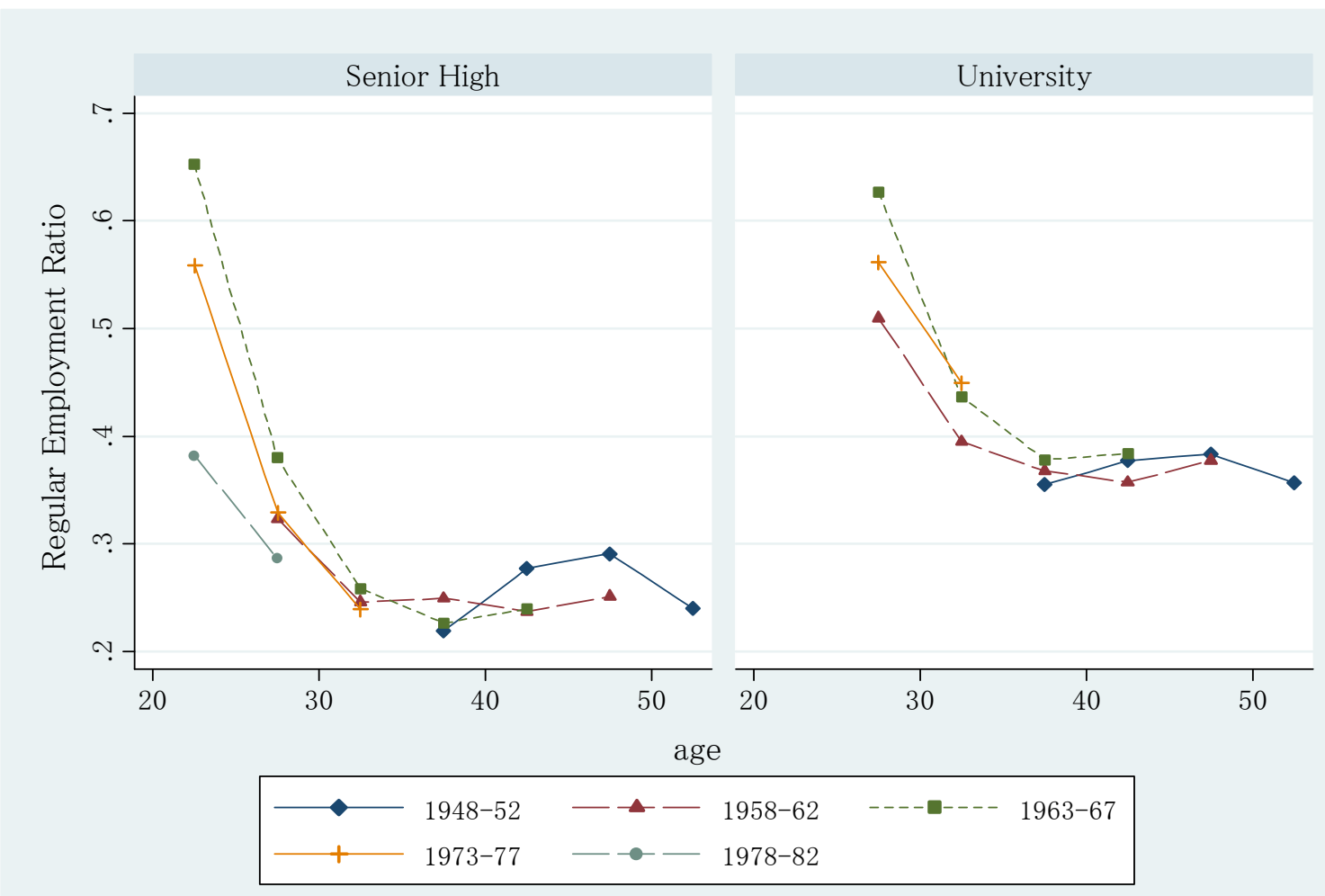

Source: ESS, 1987-2007 (published version \& resampled data) 
Figure 4: The female-to-male ratio of the RER

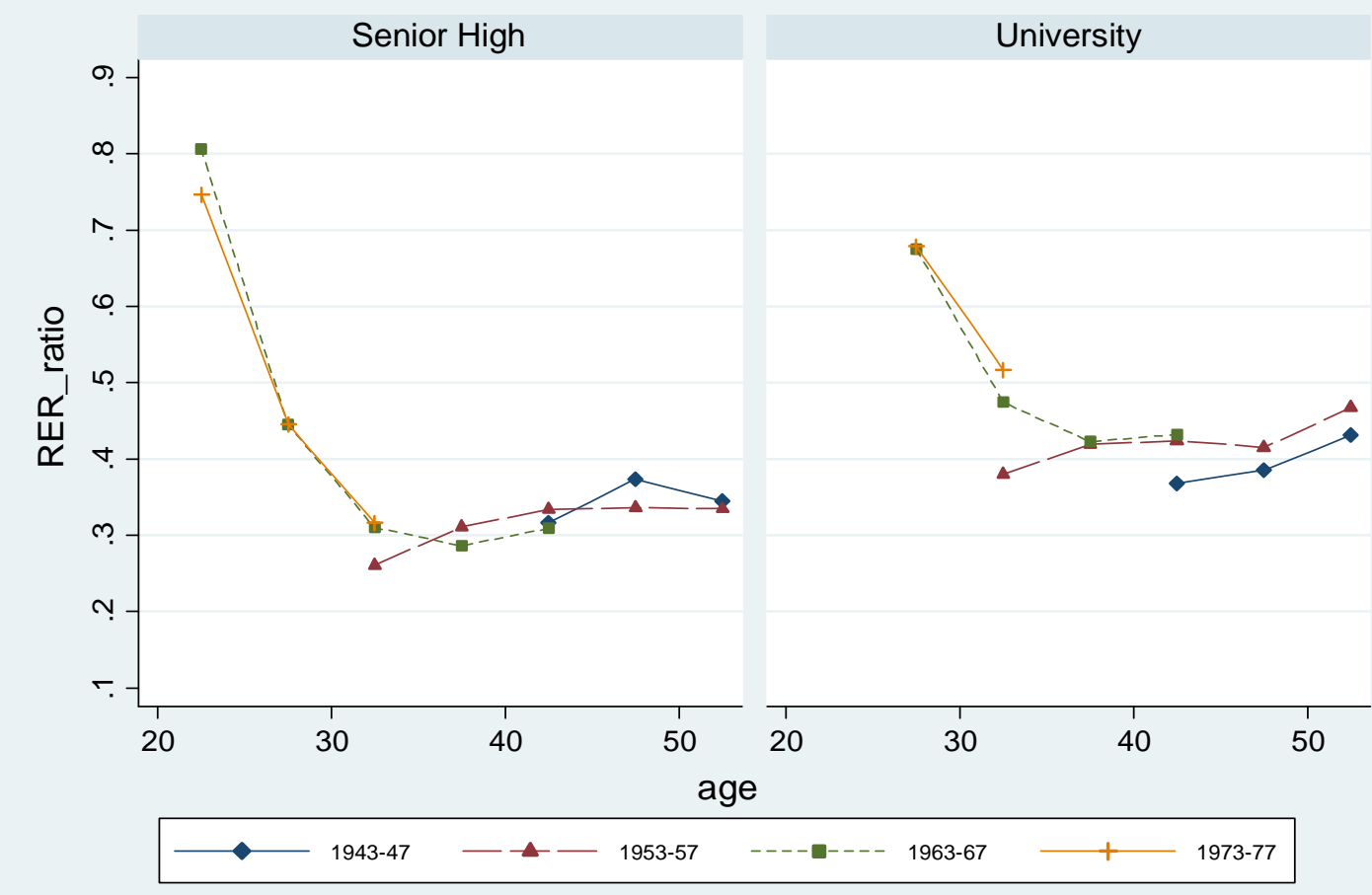

Source: ESS, 1987-2007 (published version) 


\section{Figure 5. The part-time employment ratio of women}

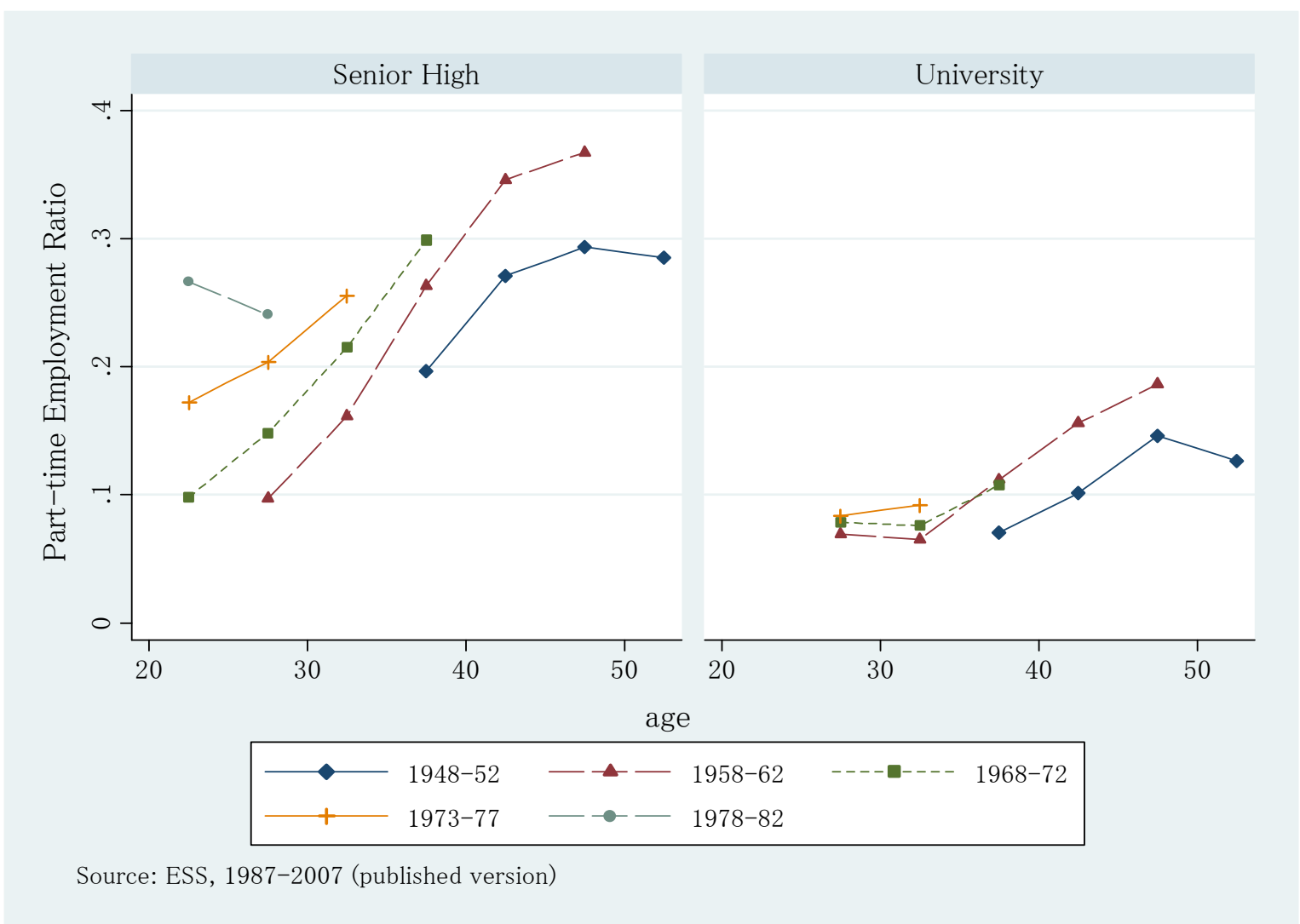


Figure 6: Regular employment ratio by marital status

\section{Married women}

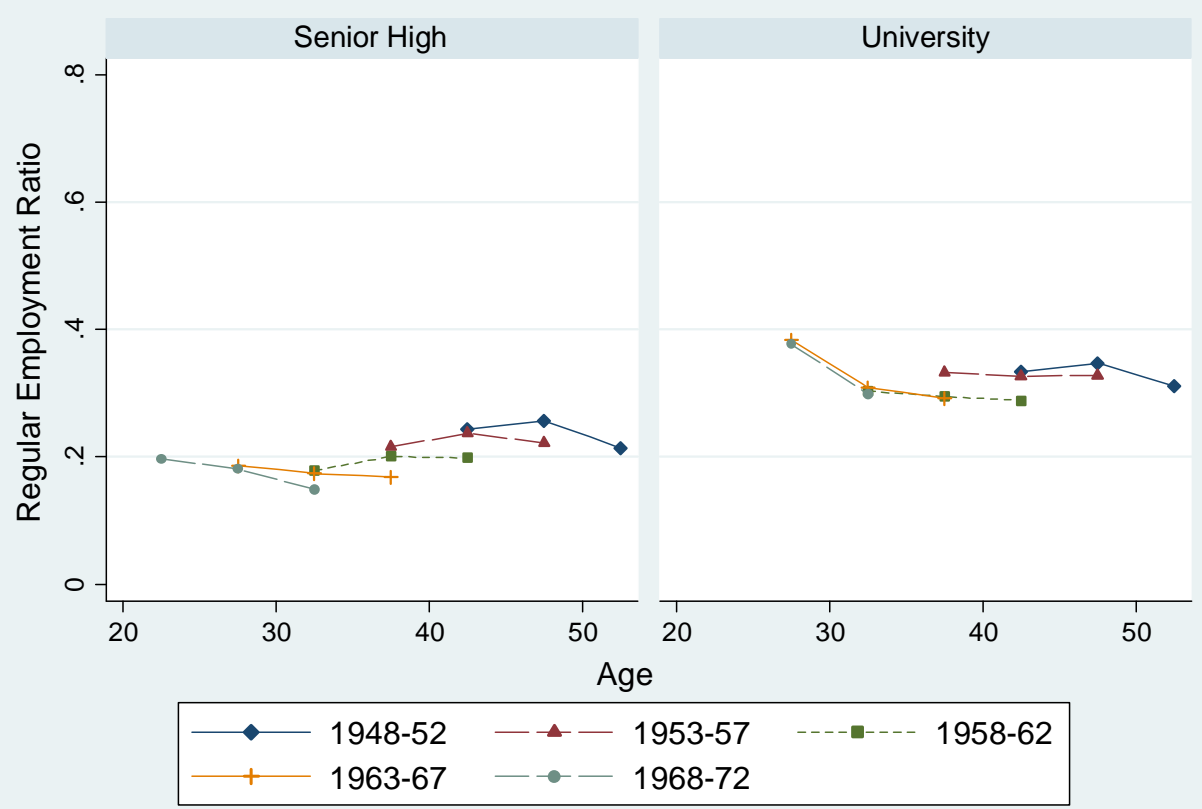

Source: ESS, 1992-2002 (resampled data)

Single women

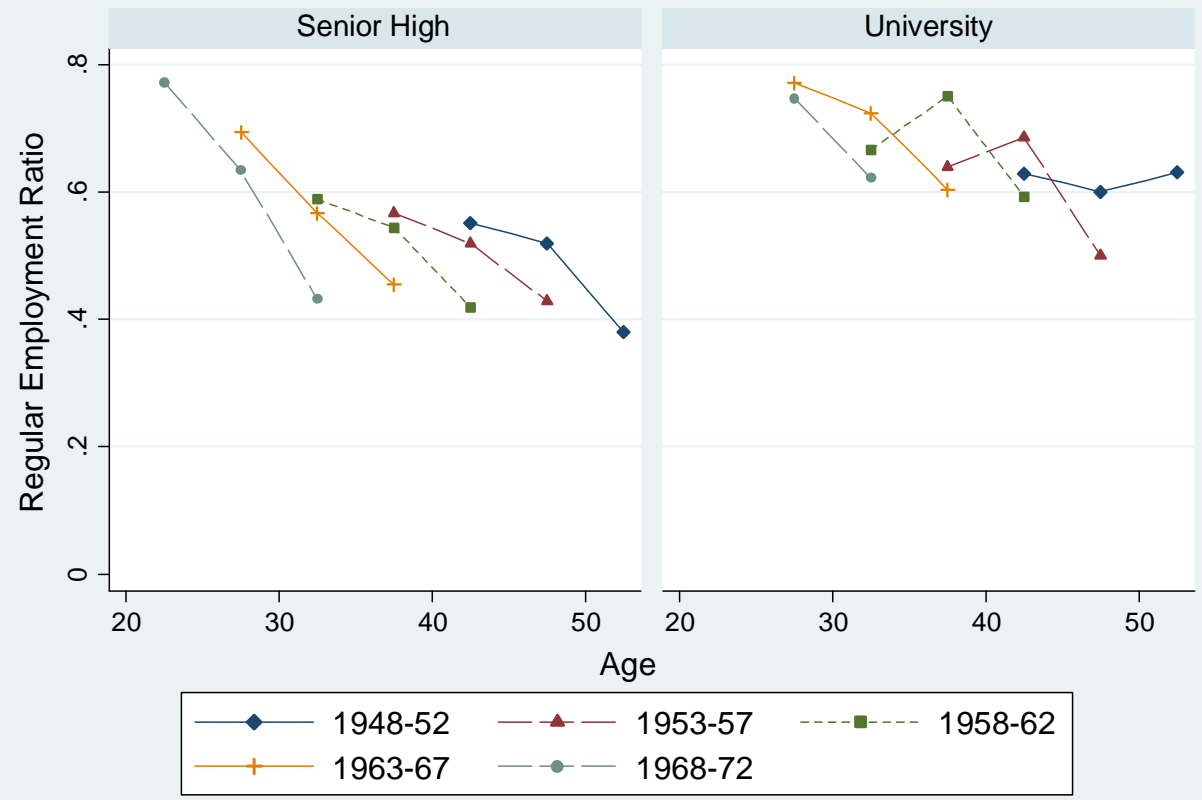

Source: ESS, 1992-2002 (resampled data) 